\section{SRUMB la sfârșit de an 2018 ...}

Apropierea sfârșitului de an este în general un moment de bilanț al împlinirilor și totodată un prilej pentru "reflexia" ultrasonografică a proiectelor de viitor. În mesajele anterioare am prezentat realizările Conferinței Naționale de Ultrasonografie a Societății Române de Ultrasonografie în Medicina și Biologie (SRUMB), organizată în acest an la Brașov, precum și pregătirile participării la congresul Euroson de la Poznan și organizarea cursurilor EFSUMB Endorsed Contrast Enhanced Ultrasound și Euroson School Liver Elastography organizate în 22 - 24 noiembrie în Centrul WFUMB Timișoara, precum și a primului curs de ultrasonografie în dermatologie - Euroson School Sonoderm Dermatologic ultrasound course organizat în 22 - 23 februarie 2019 la Cluj Napoca.

Congresul European de Gastroenterologie, United European Gastroenterology Week (UEGW), cea mai importantă manifestare a gastroenterologiei europene, oferă în fiecare an participaților un program de educație în ultrasonografie în cadrul Ultrasound Learning Area (ULA). Centrul este organizat în cooperare cu EFSUMB și promovează rolul foarte important al ecografiei pentru gastroenterolog, atât ca metodă diagnostică, dar și ca metodă terapeutică. Programul centrului constă în cursuri basic și avansate de ecografie, precum și prezentări în teme specifice de interes pentru gastroenterologi susținute de experți, ca de exemplu în acest an la Viena: ecografia gastrointestinală, ecografia în patologia pancreatică, elastografie și ecografie clinică (POCUS). Societatea Română de Ultrasono- grafie în Medicină și Biologie are un aport important în organizarea acestui centru educațional, atât prin DI Prof. Ioan Sporea, care este director al cursurilor din ULA, alături de Prof. Dieter Nürnberg (Germania) și Prof. Odd Helge Gilja (Norvegia), cât și prin ceilalți speakeri din România: Conf. Dr. Alina Popescu, Prof. Dr. Adrian Săftoiu, Prof. Dr. Zeno Spârchez, Conf. Dr. Roxana Șirli.

Sfârșitul de an este totodată propice organizării Conferinței Naționale a SRUMB din 2019, organizată la Tg. Mureș, devansat față de anunțul anterior, în 09 - 11 mai 2019, pentru a permite participarea românească la Congresul Euroson 2019, organizat la Granada, la sfârșitul lunii mai. Pentru Tg Mureș sunt în proiect patru cursuri preconferință: cursul pentru studenți, devenit tradițional, cursul de Ultrasonografie vasculară - Doppler și CEUS, tema abordată din perspectiva necesității clarificării situațiilor în care este utilizat contrastul în completarea investigării cu metoda Doppler sau în locul acesteia, cursul de Ultrasonografie toracică sau cursul de Oncodiagnostic ultrasonografic. Sesiunile științifice ale conferinței în pregătire pornesc de asemenea de la sesiuni organizate în fiecare ediție, întrucât se bucură de un auditoriu important: sesiunile de cazuri clinico-ecografice comentate, ultrasonografie mamară, musculoscheletală, ultrasonografia/elastografia părților mici superficiale, aplicarea în practică a ghidurilor EFSUMB (contrast, elastografie, intervențional, digestiv, IBD etc.) sau ultrasonografia pediatrică. În acest an sunt în dezbatere propuneri de sesiuni științifice pe teme mai rar abordate în anii precedenți: ultrasonografia tegumentară cu aplicații în oncologie, dermatologie, cosmetologie, ultrasonografia nefro-urologică, ultrasonografia în endocrinologie, ultrasonografia perinatală, ultrasonografie intervențională hepatică versus metode de biopsie ghidată ultrasonografic sau rolul ultrasonografiei în managementul complicațiilor pancreatitelor acute și cronice. Alături de aceste sesiuni vor fi organizate, ca în fiecare an, sesiunile dotate cu premii ale SRUMB - sesiunea de comunicări originale, cazuri video sau prezentările poster, între care sesiunea specială pentru tineri autori.

Practicienii tineri ai ultrasonografiei vor $\mathrm{fi}$ invitați să candideze în cadrul societății cu participări la sesiunea Young Investigator din cadrul Congresului Euroson 2019 de la Granada.

În pregătirea celor două conferințe, alături de colegii din Comitetul Director al SRUMB, transmit tuturor membrilor SRUMB, care sunt totodată și membri EFSUMB, precum și tuturor membrilor EFSUMB din toate colectivele europene, cele mai frumoase gânduri și urări pentru împliniri profesionale dintre cele mai importante în Noul An 2019!

\section{Prof. Viorela Enăchescu}

Președinte executiv al SRUMB/2018 - 2020 